Wright State University

CORE Scholar

3-1993

\title{
The Social Gospel and Socialism: A Comparison of the Thought of Francis Greenwood Peabody, Washington Gladden, and Walter Rauschenbusch
}

Jacob Dorn

Wright State University - Main Campus, jacob.dorn@wright.edu

Follow this and additional works at: https://corescholar.libraries.wright.edu/history

Part of the History Commons

\section{Repository Citation}

Dorn, J. (1993). The Social Gospel and Socialism: A Comparison of the Thought of Francis Greenwood Peabody, Washington Gladden, and Walter Rauschenbusch. Church History, 62 (1), 82-100.

https://corescholar.libraries.wright.edu/history/26

This Article is brought to you for free and open access by the History at CORE Scholar. It has been accepted for inclusion in History Faculty Publications by an authorized administrator of CORE Scholar. For more information, please contact library-corescholar@wright.edu. 


\title{
The Social Gospel and Socialism: A Comparison of the Thought of Francis Greenwood Peabody, Washington Gladden, and Walter Rauschenbusch
}

\author{
JACOB H. DORN
}

For American Protestants who were sensitive to the profound social disruptions associated with rapid industrialization and urbanization in the late nineteenth century, the twin discoveries of the "alienation" of the working class from Protestant churches and of a rising and vibrant socialist movement caused much consternation and anxious soul-searching. Socialism offered not only a radical critique of American political and economic institutions; it also offered the zeal, symbols, and sense of participation in a world-transforming cause often associated with Christianity itself. The religious alienation of the working class and the appeal of socialism were often causally linked in the minds of socially-conscious Protestant leaders.

It is not surprising, therefore, that one of the pioneer historians of the Social Gospel, Charles Howard Hopkins, should call socialism "the midwife and nurse to the social gospel." "Beyond the catalytic effect of liberal theology itself," he wrote, "no single force so stung American Protestantism into social action as did this gadfly of capitalism."l Though none made so bald an assertion as this, the other prominent historians of the pre-World War I Social Gospel-James Dombrowski, Henry F. May, and Robert T. Handy-all gave serious attention to this movement's encounter with socialism. ${ }^{2}$ Given the importance that these historians attributed to the nexus between Christian social thought and socialism, the subject has received relatively little attention in the last forty years, and it deserves fresh examination. ${ }^{3}$

1. Charles Howard Hopkins, The Rise of the Social Gospel in American Protestantism, l865-19l5 (New Haven, 1940), p. 244.

2. James Dombrowski, The Early Days of Christian Socialism in America (New York, 1936); Henry F. May, Protestant Churches and Industrial America (New York, 1949; reprint, 1967); Robert T. Handy, "Christianity and Socialism in America, 1900-1920," Church History 21 (1952): 39-54.

3. Works that give little or no attention to socialism include Ronald C. White, Jr., and C. Howard Hopkins, The Social Gospel: Religion and Reform in Changing America (Philadelphia, 1976), and Donald K. Gorrell, The Age of Social Responsibility: The Social Gospel in the Progressive Era, 1900-1920 (Macon, Ga., 1988). The relationship is central in Richard

Mr. Dorn is professor of history in Wright State University, Dayton, Ohio. 
This paper opens one important window on the subject of the Social Gospel and socialism by comparing the assessments of socialism made by three men who were indisputably in the front rank of Social Gospel thinkers. Francis Greenwood Peabody, Washington Gladden, and Walter Rauschenbusch all worked from similar assumptions: that the Christian faith, though addressed to individuals, had social implications; that the church in its corporate capacity must deal with social issues; that socialism could not be ignored; and that positive social change must come through gradual, nonviolent means, among others. They saw each other as fellow workers in the cause of Christian progress. Likewise, all three gave sustained attention to socialism. Yet each of them accented Social Gospel themes in a distinctive way, and each appraised the meaning of socialism (and, thus, its possible relationship with Christianity) differently. Studied in comparison, they demonstrate both that socialism loomed large in the thinking of key Social Gospel leaders and that, in its approach to socialism, the Social Gospel was hardly monolithic. ${ }^{4}$

"Socialism," like "Christianity," is susceptible of more than one meaning. In its loosest usage, it could mean little more than unselfishness, or social cooperation, the opposite of "individualism." More concretely, it could mean an organized political and economic movement and/or a formal ideology. It is important to recognize that these-and other-distinctions were not always observed in public discourse. Like many of their contemporaries both inside and outside the socialist movement itself, Peabody, Gladden, and Rauschenbusch often slid from one meaning to another without careful definition. The term might mean, at one time, an attitude or social spirit; at another, the "scientific socialism" of Karl Marx or its summation in the platforms of socialist parties; and at still another, a surging, idealistic move-

B. Dressner, "Christian Socialism: A Response to Industrial America in the Progressive Era" (Ph.D. diss., Cornell University, 1972); Robert H. Craig, "Seek Ye First the Political Kingdom: Christians and Socialism in the United States, 1890-1940" (Ph.D. diss., Columbia University, 1975); and Peter J. Frederick, Knights of the Golden Rule: The Intellectual as Christian Social Reformer in the 1890s (Lexington, Ky., 1976). Craig and Frederick criticize middle-class Christian radicals in this period for failing to commit themselves to a class-conscious movement.

4. William McGuire King has offered a provocative categorization of the Social Gospel, based on how three major figures in the movement, including two of these three subjects, appropriated Jesus' teachings to their own time. For Shailer Mathews, Jesus was "the transformer of culture"; for Peabody, he was "the scientific philanthropist"; for Rauschenbusch, "the nonviolent radical." These categories correspond to three types of the Social Gospel King has found in American Methodism: "social evangelism," "social engineering," and "social reconstructionism." I selected my subjects because of the intrinsic interest of their views of socialism, not because they fit King's categories. Though Gladden would not serve as a stand-in for Mathews, King's interpretation of Peabody and Rauschenbusch corresponds very closely to my findings. William McGuire King, "The Biblical Base of the Social Gospel," in Ernest R. Sandeen, ed., The Bible and Social Reform (Philadelphia, 1982), pp. 59-84; and idem, "The Emergence of Social Gospel Radicalism: The Methodist Case," Church History 50 (1981): 436-449. 
ment of industrial workers and their allies in other social groups. Orthodox Marxists, of course, had no use for such sloppiness: without the ideology, there could be no true socialism. Many socialists, however, were drawn to the movement not by philosophical or even economic doctrine, but by its appeal to a sense of justice, its historical sweep, or a desire for human solidarity. It should not be remarkable, therefore, to find that Marx was not necessarily the touchstone of socialism for Social Gospel leaders.

A professor of ethics and theology at Harvard from 1880 until his retirement in 1913, the Unitarian Francis Greenwood Peabody (1847-1936) was the most conservative of the three on social issues. ${ }^{5}$ The son of the minister at the King's Chapel, he found his education uninspired by the Unitarian orthodoxy of Harvard College and Divinity School. In Germany in the early 1870s, he tried Heidelberg, and then Leipzig, but was frustrated by the "arid rationalism" of the former and the "defensive orthodoxy" of the latter. At Halle, he found in the pietist mysticism and friendliness of Friedrich A. G. Tholuck a more congenial model of Christianity. He also absorbed the scientific-historical approach to the Bible and religion and became convinced that scholarship did not necessarily invalidate faith. ${ }^{6}$ In his career as theologian and ethicist, he combined a strong commitment to the inductive method and a profound interest in individual religious and moral experience.

Peabody was one of the first American academicians to teach a course on social ethics. The field was new, and he groped even for a name for his course, which eventually became a separate department, before adopting

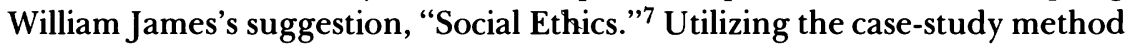
to elucidate ethical principles for charity work and municipal reform, he soon became a noted spokesman for the Social Gospel. In the 1890s he appeared before the World's Parliament of Religions and at Chautauqua, and when his own denomination established a social-service department in 1908 , he wrote and spoke for it. ${ }^{8}$

From first to last, Peabody was suspicious of precipitate action —of what he considered the nostrums and cure-alls of cranks and propagandists. Blue-

5. On race relations, for example, Ralph Luker places Peabody right of the center of the Social Gospel, and Gladden left of that center; he finds in Rauschenbusch the "personalist" emphasis that would nourish Martin Luther King, Jr. Ralph E. Luker, The Social Gospel in Black and White: American Racial Reform, l885-l9l2 (Chapel Hill, N.C., 1991), pp. 230, 315-324.

6. Tholuck, Peabody wrote, "impressed himself chiefly by the singular purity and charm of his character and the daily habit of his kindly life." Francis G. Peabody, Reminiscences of Present Day Saints (Boston, 1927), pp. 69, 83-84. See also Jurgen Herbst, "Francis Greenwood Peabody: Harvard's Theologian of the Social Gospel," Harvard Theological Review 54 (1961): 45-69; and David Robinson, The Unitarians and the Universalists (Westport, Conn., 1985), pp. 133-136, 305-306.

7. Dombrowski, Early Days of Christian Socialism, pp. 63, 69; Hopkins, Rise of the Social Gospel, pp. 91-92, 167-168; Peabody, Reminiscences, pp. 135-137.

8. Hopkins, Rise of the Social Gospel, pp. 116, 163, 292-293. 
prints for society only interested him as objects of criticism. His first major work was Jesus Christ and the Social Question (1900). Instantly popular, it was reprinted five times by 1903 and translated into several languages. ${ }^{9}$ Its principal themes reappeared virtually unchanged, and often in identical phrasing, in Jesus Christ and the Christian Character (1913) and The Christian Life in the Modern World (1914). It is not too much to say that socialism stands in polar opposition to Christianity in all three books, and that Jesus Christ and the Social Question is preoccupied with it.

Peabody opened this book by noting that agitation for social change had become a dominant feature of the age. This agitation was marked by "radical intention" (or "scope of reconstructive purpose") and "ethical passion" (or "sense of wrong"), and also by a seeming kinship with the spirit of Christianity. Yet "nothing [was] in fact more conspicuous" than its irreligion. Though the estrangement between church and social protest was widespread, socialists, influenced by German philosophical materialism, displayed a particular "antipathy to spiritual ideals." "It is not enough to say that the socialist programme is indifferent to religion," he wrote. "It undertakes to provide a substitute for religion ... a an alternative to the Christian religion." Peabody granted that the link between philosophical materialism and socialist economic analysis might have been fortuitous- - "a perversion of its characteristic aim, which can have occurred only through an unfortunate historical accident"- but for him that link was nonetheless fatal. ${ }^{10}$

As for those who attempted to ground socialism in the Christian faith, Peabody viewed their effort as unhistorical and unbiblical. He dismissed attempts by Ernst Renan (Life of Jesus, 1863), Francesco Nitti (Catholic Socialism, 1890), and George D. Herron (Between Caesar and Jesus, 1899) to make Jesus a revolutionary figure and the primitive church a normative or successful model of collective ownership. Not only were such claims unsupported by a close examination of the biblical record, Peabody's analysis of which was heavily fortified with German citations; even if their views were correct, to seek a "literal reproduction" of first-century practices was simply to "run away" from the circumstances of modern economic life. ${ }^{11}$

For Peabody, Jesus was "not a reformer but a revealer," "not primarily an

9. Hopkins, Rise of the Social Gospel, p. 207; Herbst, "Peabody," p. 58.

10. Francis G. Peabody, Jesus Christ and the Social Question: An Examination of the Teaching of Jesus in Its Relation to Some of the Problems of Modern Social Life (New York, 1900), pp. 5, 9, 13-15, 18-20. Antisocialist writers often screeched both about socialist atheism and about the antifamily and free-love proclivities of some socialists. Peabody was not as hysterical as some writers but also saw in socialism an assault on the family. See ibid., pp. 139-144; idem, The Christian Life in the Modern World (New York, 1914), pp. 38-42.

11. Peabody, Jesus Christ and the Social Question, pp. 24-28, 57-63; idem, Jesus Christ and the Christian Character: An Examination of the Teaching of Jesus in Its Relation to Some of the Moral Problems of Personal Life (New York, 1913), pp. 6, 198; idem, The Christian Life in the Modern World, pp. 26-27, 85, 112-113. 
agitator with a plan, but an idealist with a vision." The mission of this Jesus had been "religious"- - "the disclosure to the human soul of its relation to God"-and he refused to let social conditions divert him from it. ${ }^{12}$ This interpretation rested on Peabody's firm conviction that correct hermeneutical principles must begin with the great diversity and "occasionalism" of Jesus' teachings. Jesus was not systematic but responded to each individual he encountered in a specific context. All attempts to force a literal or programmatic interpretation upon the Gospels ignored that fact. Peabody insisted on moving from the "letter" to the "spirit" (Jesus' "general habit of mind") to draw out inductively the principles behind occasional utterances. ${ }^{13}$

Though Peabody believed that Christian faith had social consequences, one searches his books in vain for principles of social equity or an imperative of justice in the relationships of social groups. Jesus' social ideal centered on the idea of the Kingdom of God, which was both present within individuals and coming as "an unfolding process of social righteousness." 14 Jesus' method, however, was to regenerate individuals, who would then advance the process: Jesus "approaches the social question from within; he deals with individuals; he makes men"- "first persons fit for the Kingdom, then the better world." 15

Socialists started at the wrong end by proposing "a sheer material, external rearrangement of possessions and facilities," when the real problem was "not a mechanical difficulty, but a moral fault." Not only that, but they naively presumed to erect a social system that required unselfishness and cooperation without providing any means for promoting such virtues. External changes could not transform those "who are now brutally self-seeking and cynically cruel, into agents of magnanimity, fraternity, and justice." 16

Peabody emphasized repeatedly that progress rested on "character." In personal life, character meant poise, simplicity, peace, and grace; applied by the individual to social life, it meant sacrifice, service, and idealism. ${ }^{17}$ Neither Jesus' teachings nor modern conditions supported the conclusion that Christian character could not flourish under capitalism. Nor was there any reason to indict the rich as a class. Jesus simply did not judge individuals by economic categories. Rather, he spoke of wealth as a "trust"; only when its

12. Peabody, Jesus Christ and the Social Question, pp. 77-79; idem, Jesus Christ and the Christian Character, p. 6; idem, The Christian Life in the Modern World, p. 28.

13. Peabody likened his hermeneutic to the case method in legal studies. Peabody, Jesus Christ and the Social Question, pp. 80-82; idem, Jesus Christ and the Christian Character, pp. 74-75; idem, The Christian Life in the Modern World, pp. 27, 30-31.

14. Peabody, Jesus Christ and the Social Question, p. 102.

15. Ibid., p. llo; Peabody, Jesus Christ and the Christian Character, p. 16.

16. Peabody, Jesus Christ and the Social Question, pp. 122, 118; idem, Jesus Christ and the Christian Character, pp. 9, 15-16; idem, The Christian Life in the Modern World, p. 82.

17. Peabody, Jesus Christ and the Christian Character, chs. 5-6. 
use failed the test of stewardship was it "a peril to be escaped." Sound exegesis prohibited taking his judgments on the rich literally. ${ }^{18}$

Peabody was rather sanguine about industrial conditions in his own day. Industrial conflict was "at bottom not an economic antagonism at all," but rather an expression of "moral distrust" on the part of the working class, which businessmen could alleviate through careful experiments with industrial cooperation. ${ }^{19}$ Any economic system could be abused by bad people, while conversely, any system, including capitalism, might be "sufficiently effective and just." 20 The system was secondary and really meant little; character was not only primary, but, in Peabody's view, virtually the whole of the matter.

Washington Gladden (1836-1918), pastor of the First Congregational Church of Columbus, Ohio, shared Peabody's beliefs that Christianity begins by transforming individuals and that socialism slighted "character." His view of the interplay between the individual and social forces, however, led him to argue that the regeneration of persons and structural change must be concurrent. Though he also rejected socialism, he saw it as more than mechanical tinkering and tried to identify its affinities with Christianity. His experiences as an urban pastor also informed his thinking in ways that Peabody's studies seem not to have done. ${ }^{21}$

Gladden was an idealist who judged society by principles of harmony and fairness he considered constant. He was also a pragmatist who tested programs by their workability and emphasized the next steps to be taken. His ideas about labor relations, race, municipal reform, and poverty reveal great flexibility in the light of changing conditions and fresh information. Nothing illustrates this flexibility better than his remarkable shift from paternalistic criticisms of trade unions in the 1870 s to a grudging acknowledgment in the mid-1880s that if conflict was to govern industrial relations, workers must be able to protect their interests. ${ }^{22}$ Social conflict was not ideal, but justice demanded that one side not tyrannize the other.

Gladden's appraisals of socialism extended from the mid-1880s to the 1910s and appeared in unpublished sermons, numerous articles, and several of his books. Though many points of emphasis remained unchanged in these years, a growing understanding of social discontent and increasing impatience with American capitalists are discernible. In these appraisals, Gladden assumed

18. Peabody, Jesus Christ and the Social Question, ch. 4.

19. Peabody, Jesus Christ and the Social Question, pp. 271-272; idem, The Christian Life in the Modern World, pp. l16, 133-134.

20. Peabody, Jesus Christ and the Social Question, p. 297.

21. Jacob H. Dorn, Washington Gladden: Prophet of the Social Gospel (Columbus, Ohio, 1967).

22. Gladden's increasing support of unions can be traced from his Working People and Their Employers (1876), through "Is It Peace or War?" in his Applied Christianity: Moral Aspects of Social Questions (Boston, 1886), pp. 102-145, to his The Labor Question (Boston, 1911). A comprehensive account is in Dorn, Gladden, ch. 8. 
the role of moderate interpreter of the pros and cons-or, as he put it in his first piece on the subject, the "strength and weakness" - of socialism. ${ }^{23}$

Gladden never accepted Karl Marx's doctrines of economic determinism, surplus value, class conflict, and the historical mission of the proletariat. He often admitted, however, that the socialist indictment of capitalism was "substantially correct": workers' wages had grown less rapidly than the national wealth, frequent depressions made their lives insecure, and they saw few avenues of escape, while business concentration and "plutocracy" grew apace. In his view, it was not capitalism per se that was wrong but, rather, a false view of society, in which the "sole motive power is self-interest." ${ }^{24} \mathrm{~A}$ response to the "unsocialism" of laissez faire, whose most extreme spokesman, Herbert Spencer, was one of Gladden's chief villains, socialism was the "reaction of a scourged and outraged humanity against the greed and rapacity of the individualistic regime." ${ }^{25}$ Laissez faire meant not only "let well-enough alone," but also "let ill-enough alone," on the theory that "ill-enough, if let alone long enough, will turn to well-enough." And that was patently false. Moreover, the vaunted freedom of competitive theory was "a very illusory possession" for women and children who had to bargain with powerful employers: "freedom to take what is offered or starve." 26 Speaking to his denomination's national council in 1889 , Gladden remarked: "If I were shut up to the alternatives of Individualism with its fierce survival of the strongest and Socialism with its levelling tendencies, I should take my stand with the Socialists. ... We ought to favor state action whose purpose it is to improve the condition of the poorest and least fortunate classes ... the real motive of Socialism." 27 Nineteenth-century individualism would have to yield to "fraternity." 28

"Intelligent socialists" simply wanted a political economy that provided "equal opportunities for all and special privileges for none" and spread social burdens evenly. "Surely," Gladden wrote, "Christianity demands nothing less than this." The weakness of socialism was not in its complaint, but in its

23. Washington Gladden, "The Strength and Weakness of Socialism," Century 31 (1886): 737-749; reprinted as ch. 3 in Applied Christianity. For other examples of this approach, see Gladden, "The Use and Abuse of Parties," Century 28 (1884): 170-175 and Moral Gains and Losses of the Temperance Reformation (Charlottesville, Va., 1895).

24. Gladden, "The Strength and Weakness of Socialism," pp. 739, 741.

25. Washington Gladden, Tools and the Man: Property and Industry Under the Christian Law (Boston, 1893), p. 255.

26. Washington Gladden, sermon delivered at First Congregational Church of Columbus, 23 Jan. 1898, reel 28 (microfilm ed., 1972), Washington Gladden Collection, Ohio Historical Society, Columbus, Ohio. See his "Socialism and Unsocialism," Forum 3 (1887): 122-130, and "Moral Tendencies of Existing Industrial Conditions," Outlook 63 (1899): 871-877.

27. Carl H. Voss, "The Rise of Social Consciousness in the Congregational Churches: 1865-1942" (Ph.D. diss., University of Pittsburgh, 1942), pp. 55-56.

28. Gladden, sermon delivered 6 Jan. 1901, reel 32, Gladden Collection. 
methods and remedy, and it was here that Christians took exception to it. ${ }^{29}$ When Gladden turned to criticism, he did so at two levels: one involved his objections to structural features of a socialist society; the other involved what he considered a fundamental difference over the dynamics of social change. In 1886, taking Laurence Gronlund's The Cooperative Commonwealth (1884) as a blueprint, Gladden feared a bureaucracy that "would break down under its own weight," a deadening sameness in consumer goods, a loss of individual freedom, and devaluation of both inventiveness and managerial talent. ${ }^{30}$ Similarly, in 1893 he faulted socialism for undervaluing "the functions of mind in production," being "too vast for human power" (especially with regard to determining wants, needs, and compensation), and seeking "creature comfort" at the expense of character. ${ }^{31}$

"Character" was of special significance to Gladden as it was to Peabody. He did not, however, push his critique to total rejection of socialism. His concern was to balance collective action through government, on one hand, and personal freedom and responsibility, on the other. He told his congregation: "We must never imagine that the government of the state or the nation can be turned into a good fairy that shall empty the horn of plenty at every man's door and let him consume without care what has been gathered without toil. ... If we ask the state to relieve us of the responsibility of caring for ourselves, we simply ask to be stripped of the highest prerogative of manhood." 32 "For my own part, while I am willing to extend the sphere of the state in certain directions, I am very clear that I do not wish to have it extended until it covers the whole of life," he said on another occasion. To make the state a "Colossal Providence" rather than a "Guarantor of Equal Opportunities" would be "to do what the infinite Benevolence refuses to do." Legitimate though it was, the reaction against individualism might go too far. ${ }^{33}$ The proper analogy for society was neither the "sand-heap" (individualism) nor the "chemical compound" (socialism), but the human organism, each part of which "is one" but "finds its life in the life of the larger unity." Without substantial freedom to own and use property, individual identity and character development would be in jeopardy. ${ }^{34}$

Gladden welcomed the growth of government, which in a democracy was only an agent of "the economic and social cooperation of all the people for

29. Washington Gladden, "Christianity and Socialism," Chautauquan 30 (Nov. 1899): 138141.

30. Gladden believed that profit sharing experiments would avoid these dangers and supported them until the mid-1890s when their paternalism became apparent to him. Gladden, Applied Christianity, pp. 86-94.

31. Gladden, Tools and the Man, pp. 260-270. He repeated some of these and other strictures in Christianity and Socialism (New York, 1905), p. 122.

32. Gladden, sermon delivered 27 May 1894, reel 25, Gladden Collection.

33. Gladden, sermon delivered 23 Sept. 1894, reel 26, Gladden Collection.

34. Washington Gladden, Ruling Ideas of the Present Age (Boston, 1895), pp. 81-82, 77. 
the common good." 35 A proponent of incremental increases in the regulatory and welfare functions of government, he also advocated public ownership of "natural or virtual monopolies" and anticipated that public ownership might eventually include other economic enterprises. ${ }^{36} \mathrm{He}$ envisioned, in short, a mixed economy and objected not to significant increases in state power, but to the speed and scope of the socialist approach.

The second level on which Gladden criticized socialism involved the relative importance of individual regeneration and structural change. He displayed little concern over the antipathy of some socialists to religion; unlike Peabody, who saw in socialism only a "material, external rearrangement of possessions and facilities," he found a religious yearning for a better world akin to the Christian hope for the Kingdom of God ${ }^{37}$ But he believed that socialists focused too much on environment and neglected the task of creating socialized individuals: they would "erect the structure of economic Socialism on the basis of moral individualism." It was not, for Gladden, an either-or matter, or, as it was for Peabody, a matter of sequence. It was, instead, a matter of concurrent emphasis. "If you ask which of these must take the precedence," he wrote, "I answer neither; they must be held together." "All morality," after all, was social, not individual. ${ }^{38}$ Any conception of the individual as other than a social being who is related continually and inextricably to others through natural social groups and institutions, and by law, morals, and custom, was fallacious. In Gladden's view, Jesus recognized this when he taught the "fatherhood of God" and "brotherhood of man." Undergirded by those core Gospel realities, Christianity would transform both individual and society. ${ }^{39}$

"Changes of form" would not change the spirit, but neither could a "change of spirit ... express itself without a change of form." New wine

35. Gladden, "The Philosophy of Anarchism," sermon delivered 29 Sept. 1901, reel 33, Gladden Collection.

36. Gladden, sermon delivered 23 Jan. 1898, reel 28, Gladden Collection; idem, "The Spread of Socialism," Outlook 62 (1899): 121; idem, "Christianity and Socialism," Chautauquan 30 (1899): 138-141; idem, Christianity and Socialism, p. 126.

37. He saw this religious and ethical dimension in Edward Bellamy's Looking Backward (1888), Laurence Gronlund's Our Destiny (1890), and Fabian writings. See Washington Gladden, sermons on Looking Backward, 1 Sept. 1889 (reel 21), Our Destiny, 19 Apr. 1891 (reel 22), and "Two Types of Socialism," 10 May 1908 (reel 40), Gladden Collection; idem, "Mr. Bellamy's Utopia," Frank Leslie's Illustrated Newspaper, 16 Aug. 1890, p. 37. Gladden opposed Bellamy over equality of rewards, which, because of differences in effort, efficiency, and ability, would in fact be inequitable. Both Gronlund and Bellamy helped to "Americanize" socialism by infusing it with religious idealism. Howard $\mathbf{H}$. Quint, The Forging of American Socialism (Indianapolis, 1953), ch. 3; Solomon Gemorah, "Laurence Gronlund's Ideas and Influence, 1877-1899" (Ph.D. diss., New York University, 1965).

38. Gladden, "Christianity and Socialism," Chautauquan, p. 140.

39. Gladden, Christianity and Socialism, pp. 9, 19, 23, 35. 
demanded new wineskins. ${ }^{40}$ The dual aims of Christianity were inseparable. To create a perfect society, Christianity must "produce perfect men"; to produce them, it must "construct a perfect society." Social structures were important: they could either "emphasize and promote the worth and goodness of men" or "belittle and discourage personal worth and goodness." 4 Gladden's attempt to balance the individual and the social was at the heart of both his criticism of socialism and appreciation of its corrective value. That socialists thought they could create the better world out of the old human nature was his fundamental criticism. That their emphasis on the social environment and on the social nature of human life was morally superior to an atomistic individualism was what made him treat them with an even hand. Peabody agreed only with the criticism.

Though Walter Rauschenbusch (1861-1918) endorsed political and economic reforms no more far-reaching than those that Gladden supported, his engagement with socialism was more intimate and passionate than Gladden's. He identified more fully with socialist ideals, spoke and wrote under party auspices, and contemplated party membership. ${ }^{42} \mathrm{He}$ exemplifies the extent to which a social gospeler could embrace socialism while remaining critically detached.

Rauschenbusch's interest in socialism began in the late 1880s. A graduate of the Rochester Theological Seminary, to which he would return as a professor in 1897, he was unprepared for the suffering he encountered as pastor of the Second German Baptist Church on Manhattan's West Side. Struggling with the church's role in society, especially its relationship to the working class, he first found help in Henry George's Progress and Poverty (1879), which identified land monopoly as the cause of poverty amidst material abundance, and then went on to read widely in other reformist literature. ${ }^{43}$

When in 1889 a Society of Christian Socialists (SCS) came into being in Boston, Rauschenbusch associated himself with its position. He visited the Boston society; he helped launch For the Right, a little paper intended to discuss working-class issues "from the standpoint of Christian socialism,"

40. Gladden, "Moral Tendencies of Existing Industrial Conditions," pp. 876-877.

41. Gladden, Tools and the Man, pp. 1-2. Gladden was not always consistent in balancing the individual and the social. A "true socialism," he declared, would "socialize the individual," rather than change society by "outward pressure." But he still insisted that Christianity encompassed both. Gladden, Christianity and Socialism, pp. 185, 306.

42. His first biographer considered Rauschenbusch "a convinced socialist," and a recent writer thinks he "came about as close as one possibly could to embracing socialism without joining the party." Dores R. Sharpe, Walter Rauschenbusch (New York, 1942), p. 219; see also Frederick, Knights of the Golden Rule, p. 155.

43. Walter Rauschenbusch, Christianizing the Social Order (New York, 1912), p. 394; Sharpe, Rauschenbusch, pp. 195-196; Frederick, Knights of the Golden Rule, pp. 148-150; Paul Minus, Walter Rauschenbusch: American Reformer (New York, 1988), pp. 60-65. Though Rauschenbusch found George's emphasis on land too narrow, he considered it important and faulted socialists for neglecting it. 
which published the "Declaration of Principles" of a New York affiliate of the SCS; and he wrote for the parent organization's Dawn. ${ }^{44}$

During a sabbatical in Europe in 1891, in which he furthered his study of socialism, Rauschenbusch discovered the organizing theme for all his subsequent thinking: the centrality of the Kingdom of God in the teachings of Jesus. Upon his return, he helped found the Brotherhood of the Kingdom, a group of like-minded individuals who met annually to share papers and issue occasional publications for the next twenty years. Given often to discussions of socialism, the brotherhood provided an important setting for him to develop his ideas about the meanings of Christianity and socialism for each other-and about the place of socialism in the coming Kingdom of God..$^{45}$

The Christian socialism that Rauschenbusch embraced stood aloof not only from Marxian doctrine, but also from any socialist party. While the New York society's declaration saw in socialism "an attempt to prefigure ... in economic forms" a badly needed "higher social order," it also remarked that, "as a body, we see no need now of committing ourselves to Socialism in the sense of any specific system of economic doctrine. ... We are concerned with principles, not with methods. ... We are evolutionists, not revolutionists. ... In this sense we are Socialist, Socialist in the spirit rather than the letter." 46 Rauschenbusch moved closer to the socialist political movement as the years went on, but throughout his life he voiced serious reservations, not unlike those expressed by Peabody and Gladden, about its aims and methods.

He ordinarily placed these reservations in the context of more important convergences between Christianity and socialism. Thus in $\mathbf{1 8 9 5}$ he found common ground in the principles of human worth and social cooperation. "For working purposes I am myself a socialist," he declared. "We want more socialism than we have at present, anyway." ${ }^{7}$ Yet socialism carried grave dangers: a loss of individual freedom; a tendency to weaken the family and love of country; a proclivity to expect sudden change through force; and a "practical materialism" that overemphasized "improved arrangements and facilities." Like Peabody and Gladden, Rauschenbusch reserved his strongest language for the socialist threat to freedom and over-reliance on structural

44. For the organization of the Boston and New York societies, see Dawn 1 (15 May 1889): 3-4 and ibid. (Feb. 1890): 5. For Rauschenbusch's involvement see Sharpe, Rauschenbusch, p. 86; Minus, Rauschenbusch, p. 67; and Walter Rauschenbusch, "London Letter," Dawn 3 (July 1891): 9-11. Though W. D. P. Bliss, the SCS's organizer, spoke in Gladden's church and Gladden wrote for the Dawn, Gladden did not call himself a Christian Socialist. See "Mr. Bliss's Lecture Trip," Dawn 2 (June 1890): 93-94; Washington Gladden, "The Eight-Hour Problem," ibid. (July-Aug. 1890): 137-147.

45. Minus, Rauschenbusch, chs. 5-6; Sharpe, Rauschenbusch, ch. 7; Charles Howard Hopkins, "Walter Rauschenbusch and the Brotherhood of the Kingdom," Church History 7 (1938): 138-156.

46. Sharpe, Rauschenbusch, pp. 91-92.

47. Walter Rauschenbusch, "The Ideals of Social Reformers," American Journal of Sociology 2 (September 1896): 203, 209, 211. 
change. He feared that the socialist state might become a "collosal machine," which - to change the metaphor, as he did-would make individuals like "barnyard fowl, assiduously laying eggs, but without wing enough to fly over the fence." He also disdained social reconstruction without personal regeneration: "We might have streets as smooth and clean as a Paris boulevard, and the people on it might yet be a libidinous lot, working out their own destruction." 48 These were dangers, however, not reasons for rejecting socialism, and Christians "ought to join in it exactly to avert" them. ${ }^{49}$

What "join[ing] in it" might mean for Christians remained unclear in this and all of Rauschenbusch's subsequent pronouncements on socialism. His distaste for Marxism was acute, and when he called himself a socialist he was expressing at most a sympathetic outsider's support for the gradualistic program of political-actionists within the American socialist movement. Speaking to a predominantly socialist audience in Rochester in 1901, for example, he affirmed their goal of social ownership of the means of production and distribution but distinguished between a "dogmatic socialism," which was apocalyptic in expectation, materialistic in philosophy, and dogmatically authoritarian, and a "practical socialism," which worked for expansions of public ownership, inheritance taxes, strong unions, and protective labor laws. He affirmed the latter but rejected the former on both theoretical and practical grounds. ${ }^{50}$

The Socialist Party of America that was taking shape in 1901, partly in reaction to the doctrinaire character and ineffectiveness of the older Socialist Labor Party, was strongly oriented toward the kind of "practical socialism" that commended itself to Rauschenbusch. ${ }^{51}$ Nevertheless, even when identifying affinities between Christianity and socialism, he continued to articulate

48. Ibid., pp. 211-218. Winthrop S. Hudson has emphasized the necessity of personal religious experience for Rauschenbusch in "Walter Rauschenbusch and the New Evangelism," Religion in Life 30 (1961): 412-430, and Walter Rauschenbusch: Selected Writings (New York, 1984).

49. Rauschenbusch, "Ideals of Social Reformers," p. 219. Rauschenbusch explained why the church should be interested in social conditions in a subsequent article, "The Stake of the Church in the Social Movement," American Journal of Sociology 3 (July 1897): $18-30$.

50. "Socialism is of Two Kinds: The Practical and the Dogmatic Contrasted," Rochester Democrat and Chronicle, 25 Feb. 1901. He criticized Marxists' emphases on surplus value and the industrial proletariat, argued that authoritarianism made their scientific pretensions mere "cant," and accused them of "turn[ing] one of the sublimest movements the world has ever seen into the squealing of a drove of pigs where the rear pigs are trying to push away the front pigs and get their noses into the trough too." Practically, he argued that refusal to work for short-term gains would expose workers to further mental and physical degradation and leave them unprepared to administer socialist institutions when the new order came. Sharpe incorrectly considered this lecture Rauschenbusch's most representative treatment of socialism and included it in Rauschenbusch, pp. 203-216.

51. David A. Shannon, The Socialist Party of America: A History (New York, 1955), chs. 1-2. 
features of socialism that he found objectionable. In Christianizing the Social Order (1912), for example, he focused on socialist antagonism to the church as an "alloy" that repelled Christians from socialism who otherwise saw in it "the most thorough and consistent economic elaboration of the Christian social ideal" and "the most powerful force for justice, democracy, and organized fraternity in the modern world." Noting the German origins of the antireligious animus, the Socialist Party's stated neutrality toward religion, and the involvement of many ministers in the party, he concluded that antagonism toward religion was "in no way essential to Socialist thought." It made it hard for those like him who had "drawn their economic insight from Socialism," however, "to cooperate whole-heartedly with party socialism as they actually find it." 52 His intention, he explained to Peabody, was to encourage rapprochement between party and church: "I am not going to tell the Socialists that I expect them to remain atheists. I shall tell them that they are now religious in spite of themselves and that an increased approach to religion is inevitable as they emerge from the age of polemics and dogmatism." 53 Still, hostility to religion among socialists obviously disturbed him.

Similarly, a lecture on "The Right and Wrong of Socialism," given in 1914 and 1915, included no less than eleven faults in spirit, tactics, and balance. These included, alongside his earlier complaints, an exaggerated economic determinism, inadequate emphasis on personal morality, an unrealistic estimate of the goodness and competence of the working class, and an appeal to class hatred. ${ }^{54} \mathrm{~A}$ short piece on Christian socialism, published posthumously, while identifying Christian socialists as a possible bridge between Christianity and socialism because they shared "the essential convictions" of both, insisted that they were "not a mere echo of orthodox Socialism," but were "in conscious antagonism" to its materialistic philosophy, antireligious tendencies, and neglect of individual moral responsibility. ${ }^{55}$

In a way that Gladden could not, Rauschenbusch saw himself as a mediator between Christianity and socialism. His first loyalty was to the Christian ideal of the Kingdom of God as both here and yet ever coming. But the attraction of socialism as a force working toward that Kingdom was powerful. Nowhere is this clearer than in his most famous book, Christianity and the Social Crisis (1907). Though its radicalism escaped many readers, it was a ringing endorsement of a gradualistic and idealistic socialism. Rauschenbusch grounded this endorsement in several historical chapters intended to show that "the essen-

52. Walter Rauschenbusch, Christianizing the Social Order (New York, 1912), pp. 397-403.

53. Rauschenbusch to Francis G. Peabody, 14 Dec. 1912, Box 26, Rauschenbusch Family Papers, American Baptist-Samuel Colgate Library, Rochester, N.Y.

54. Walter Rauschenbusch, Lecture notes for "The Right and Wrong of Socialism," 1914, Box 20, Rauschenbusch Papers.

55. Walter Rauschenbusch, "Christian Socialism," in A Dictionary of Religion and Ethics, ed. Shailer Mathews and Gerald B. Smith (New York, 1923), pp. 90-91. 
tial purpose of Christianity was to transform human society into the kingdom of God by regenerating all human relations and reconstituting them in accordance with the will of God." 56 Working through the prophets, Jesus, and the primitive church, he found a consistent call for a righteous society. The prophets' morality was not individualistic; it was "the public morality on which national life is founded." Jesus appropriated their message when he announced that the Kingdom of God was at hand; he was "a Hebrew prophet preparing men for the righteous social order." And the early Christian communities, organized for mutual help, exhibited "a strong leaven of democracy and protest." ${ }^{\text {" }} 7$ Anticipating the "preferential option for the poor" of later liberation theology, Rauschenbusch stated that the prophets were "almost monotonous" in siding with the poor and that Jesus' "fundamental sympathies ... were with the poor and oppressed." 58 Because conquest and captivity turned the prophetic tradition inward and Roman oppression and Gentile culture subsequently distorted the Christian church's understanding of Jesus' message of social transformation, the biblical record was not uniform; the ethical-social impulse that was its genius, however, was clear. ${ }^{59}$

Rauschenbusch agreed with Peabody that Jesus was not "a social reformer of the modern type" and insisted that he approached the problems of his day from a moral and religious point of view. ${ }^{60}$ Whereas Peabody's Jesus did not apply categories of wealth or poverty to individuals, however, Rauschenbusch's Jesus taught that riches were obstacles to the "revolutionary" Kingdom standards of justice, equality, and love. As for the early church, Peabody had found no widespread, compulsory, or successful common ownership of goods, and Rauschenbusch agreed to a point. "Generosity," not compulsion, had characterized early Christian communities. Rauschenbusch concluded, however, that economic mutuality had been fairly widespread, successful, and long-lasting. ${ }^{61} \mathrm{He}$ believed no more than Peabody that first-century practices could be applied to modern industrial conditions; he did believe that Jesus' message yielded normative principles for the structure of society and the relationships among social groups. ${ }^{62}$

When Rauschenbusch moved from the biblical record to "the present

56. Walter Rauschenbusch, Christianity and the Social Crisis (New York, 1907), p. xiii.

57. Ibid., pp. 8, 54-55, 67, 133.

58. Ibid., pp. 12-13, 82.

59. Ibid., pp. 27-31, 98-112, 152-160.

60. Ibid., pp. 47-48.

61. Ibid., pp. 81, 77, 120-133.

62. One historian considers Rauschenbusch's approach to the Bible inconsistent. More intent to find sanction for social activism than to apply the hermeneutical principles of liberal biblical scholarship consistently, he interpreted passages that fostered social passivity as "in history" and passages that undergirded activism as "absolute, timeless, infallible authority." Glenn C. Altschuler, "Walter Rauschenbusch: Theology, the Church, and the Social Gospel," Foundations 22 (1979): 140-151. 
crisis," he indicted capitalism not by implication but by name. Capitalism was responsible for the inherent inequality between those who owned and those who used the tools of production, the "chronic wretchedness" of wageearners, increasing class separation, corruption of the political process, a "tainting of the moral atmosphere," and the erosion of family life. ${ }^{63}$

After establishing the church's "stake" in this crisis, Rauschenbusch turned finally to "What To Do." His answer was complex. Individuals and churches with a social faith could do much to promote fairness and justice. As a historian, however, Rauschenbusch emphasized the collective, communal aspects of human life. ${ }^{64}$ With a strong sense of class alignment and class conflict in history, he insisted that the working class must be raised as a class if ultimate justice-an end to the class system-were ever to be achieved. Socialism promised to do that, he noted, and "if such a solution is even approximately feasible, it should be hailed with joy by every patriot and Christian."65

It is possible to read Rauschenbusch's sequel, Christianizing the Social Order, as a more complacent book. His judgment that, of all the major social institutions, only business was not already "Christianized" supports such a conclusion. But this work is also striking in its indictment of capitalism and sympathy for a practical socialism. One of several anticapitalist chapters provides a litany of contrasts between Christianity and capitalism, "a mammonistic organization with which Christianity can never be content." 66 For all his criticism of socialist irreligion, he concluded: "Socialism is one of the chief powers of the coming age. Its fundamental aims are righteous ... because they are human. They were part of the mission of Christianity before the name of Socialism had been spoken. God had to raise up Socialism because the organized Church was too blind, or too slow, to realize God's ends." 67

Rauschenbusch's socialist connections grew stronger in his last decade. The fact that two of his children, Hilmar and Winifred, were elected presidents of Intercollegiate Socialist Society (ISS) chapters at Amherst and

63. Rauschenbusch, Christianity and the Social Crisis, ch. 5.

64. Henry W. Bowden, "Walter Rauschenbusch and American Church History," Foundations 9 (1966): 237; Sherman Barnes, "Walter Rauschenbusch as Historian," ibid. 12 (July-Sept. 1969): 257; Ronald C. Massanari, "The Sacred Workshop of God: Reflections on the Historical Perspective of Walter Rauschenbusch," Religion in Life 40 (1971): 261-262. Believing that church historians' lack of interest in the common people had distorted their whole perspective, Rauschenbusch argued that church history must be "translated into the History of the Kingdom of God" and encompass all social groups. Rauschenbusch to Richard T. Ely, 17 Apr. 1903, Richard T. Ely Papers, State Historical Society of Wisconsin, Madison, Wis. (microfilm ed., 1982), reel 25.

65. Rauschenbusch, Christianity and the Social Crisis, pp. 405-408.

66. Rauschenbusch, Christianizing the Social Order, pp. 321-322, 313.

67. Ibid., p. 405. 
Oberlin colleges in 1915 suggests the congeniality of the relationship. ${ }^{68} \mathrm{He}$ spoke and wrote under Socialist Party auspices. Despite distaste for its hyperbolic style, he contributed to the party-oriented Christian Socialist, identifying Christianity and socialism as the oldest and youngest "idealistic forces at work in our civilization." 69 He addressed the Young People's Socialist League in Rochester several times and brought one of the party's leading speakers, Rose Pastor Stokes, to his seminary. ${ }^{70} \mathrm{He}$ was one of seventeen signers of a statement that explained why Progressives could vote for the Socialist presidential candidate in $1916 .{ }^{71}$ In a speech that fall to the ISS, he asserted that socialism was "here under divine compulsion," that its "moral and spiritual" appeal to him was "irresistible," and that socialists should accent the congruences between their goals and Christian beliefs. ${ }^{72}$ He shared the party's opposition to American intervention in World War I and agreed to appear at an antiwar rally it held in Rochester in February $1917 .{ }^{73}$ His contacts and correspondence with socialists were frequent and warm.

While some readers of Rauschenbusch's books saw in them only a mild Social Gospel, a significant number were moved toward socialism by his presentation of Jesus' message. Christianity and the Social Crisis helped a staff member of the International Y.M.C.A. College to deepen his understanding of socialism and to "know Jesus as I have never known him before." The Episcopalian child-welfare reformer and later Marxist author, Anna Rochester, found after reading this book that "Christianity has been so much more of a force and motive to me, and socialism has become the Christian's opportunity, in such a real sense, that I feel I owe a debt of gratitude to the

68. Hilmar Rauschenbusch to Walter Rauschenbusch, 23 Apr. 1915, Box 29, Rauschenbusch Papers.

69. Rauschenbusch to William F. Cochran, 8 Aug. 1916, Box 30, Rauschenbusch Papers; Walter Rauschenbusch, "The Imperative Demand," Christian Socialist 11 (15 Mar. 1914): 5.

70. Herman A. Sarachan to Rauschenbusch, 3 Jan. 1915, Box 99, Rauschenbusch Papers; Rauschenbusch to Harry Laidler, 6 Mar. 1914, and to Rose Pastor Stokes, 9 Mar. 1914, Rose Pastor Stokes Papers, Socialist Collections in the Tamiment Library, 1872-1956, New York University (microfilm ed.), reel 67.

71. Many other signatories were party members. "The Case for Benson," New Republic 8 (7 Oct. 1916): 243-245.

72. Harry W. Laidler to Rauschenbusch, 28 Apr. and 11 July 1916, Box 30, Rauschenbusch Papers; Walter Rauschenbusch, "The Appeal of Socialism to a Christian Mind," Intercollegiate Socialist 5 (Dec. 1916-Jan. 1917): 8-9, and "Combining Christianity and Socialism," New York Call Magazine (22 Apr. 1917) and Christian Socialist 14 (3 Jan. 1917): 1-2. In each article he used "we" when referring to socialism.

73. Minus, Rauschenbusch, p. 182. In one of his most poignant statements of the grief he felt over the war, Rauschenbusch wrote: "I am still a Socialist, and see the real causes of war in the exploiting classes and nations. I am still a Christian, and in the midst of the war have written an exposition of the Social Principles of Jesus, in which few Christians believe. I am more than ever a pacifist." Rauschenbusch to W. H. P. Faunce, 11 Feb. 1917, Box 32, Rauschenbusch Papers. 
one who made those things clear to me." A Friends pastor in Colorado and a Baptist pastor in Pennsylvania were similarly inspired. As the latter wrote, "I was inclined to Socialism before, now I am fully persuaded of it." 74 Of special importance was Rauschenbusch's influence on William F. Cochran, a wealthy Episcopalian whose conscience was troubled by Rauschenbusch's strictures on wealth, and who frequently sought Rauschenbusch's counsel about progressive and radical causes to support and contributed funds for Rauschenbusch's own work. ${ }^{75}$

Party activists not infrequently welcomed Rauschenbusch as an ally. A librarian in Oakland spoke of "my joy in finding you, socialist and brave defender." An "active class-conscious revolutionary-socialist of the deepest dye" in Oregon claimed never to have seen "a more severe indictment of our present social system" than Christianity and the Social Crisis and pronounced it "splendid propaganda, better than most of our own books." The literature agent of the Socialist local in Auburn, New York, sought permission to handle that book's sales in his city, and the socialist Rand School in New York sold both it and Christianizing the Social Order in its bookstore. Members of the Binghamton local planned to attend en masse a lecture he gave there. ${ }^{76}$

Given his willingness to link socialist and Christian ideals so closely and to veer so close to the Socialist Party orbit, and given that party's gradualistic, ballot-box orientation, the question arises why Rauschenbusch held back from membership. For Peabody, who condemned socialism, and for Gladden, who weighed its pros and cons from a distance, party membership was never an issue. Considering Rauschenbusch one of them in all but name (and, of course, a potential trophy if he would adopt the name), some socialists pressed the issue on him. One reader of Christianity and the Social Crisis asked: "Why do you not make your position clear beyond a question by a definite statement in your next edition?" 77 Two Christians in the party also tried to steer him toward an explicit affiliation. Rufus W. Weeks, vicepresident of the New York Life Insurance Company and a major contributor

74. Charles A. Ruby to Rauschenbusch, 29 Oct. 1912, Box 26; Anna Rochester to Rauschenbusch, 23 Mar. 1909, Box 25; Herbert T. Cash to Rauschenbusch, 27 Oct. 1908, Box 25; and J. G. Lauderbaugh to Rauschenbusch, 12 Apr. 1910, Box 25; Rauschenbusch Papers.

75. "I got it from you in the first place," Cochran wrote, "that the highest duty of a millionaire is to make the future rise of millionaires impossible, or something to that effect." Rauschenbusch promised to buy a typewriter with one gift and "hammer as much good Christianity and Socialism out of it as I can." William F. Cochran to Rauschenbusch, 10 Mar. 1915, and Rauschenbusch to Cochran, 11 Mar. 1915, Box 29, Rauschenbusch Papers.

76. Frederick I. Bamford to Rauschenbusch, 1 Nov. 1907, Box 25; Margaret W. Thompson to Rauschenbusch, 16 May 1912, Box 93; Charles E. Forsyth to Rauschenbusch, 19 Feb. 1908, Box 25; John Hughes to Rauschenbusch, 4 Dec. 1914, Box 28; and A. E. Breckenridge to Rauschenbusch, 7 Jan. 1914, Box 93, Rauschenbusch Papers.

77. Clarence L. Wright to Rauschenbusch, 15 June 1909, Box 25, Rauschenbusch Papers. 
to the Christian Socialist and various party institutions, saw Christianity and the Social Crisis as a call for Christians to ally with "class-struggle socialism" and corresponded with Rauschenbusch over many years about Christian socialism in the United States and Europe. ${ }^{78}$ Wellesley College's Vida D. Scudder was more direct. It was important, she wrote, "for people of our type to be within the political movement, both in order to preserve it so far as possible from that hard dogmatism of which you speak . . . and to vindicate the honor of Christianity. Nothing but party-membership convinces those men that one is in earnest. I covet you for the party. My being in it doesn't count except to myself. Yours would. It would draw many, \& we could get a political socialism of a better type." 79

There is no simple reason for Rauschenbusch's position. His oft-repeated criticisms of socialist dogmatism, atheism, and catastrophism are a partial but incomplete explanation. Personal considerations were also involved. Whether these included the long friendship he enjoyed with John D. Rockefeller, and the financial gifts he derived from it, is debatable.$^{80} \mathrm{It}$ is clearer that he had an acute sense of vulnerability to attack. He had been rejected for missionary service in 1886 for theological reasons. Baptist conservatives had criticized his biblical and social views in the $1890 \mathrm{~s}$, and his statements about socialism had delayed his permanent faculty appointment at Rochester. Christianity and the Social Crisis upset the chairman of the seminary's trustees and elicited other complaints. ${ }^{81}$ That such experiences made him wary is implied in Vida Scudder's acknowledgment of his reply to her plea that he join the party: "that a man of your acknowledged status as a sane and spiritual leader should have to plead worldly prudence as one factor in his decision is a tragic reflection on the modern Church. For me, I have few hostages with fortune. ... I thank God that you are safe at Rochester." 82

In addition to "worldly prudence" about his seminary position, a belief that party membership would weaken his influence seems to have been a factor in his decision. "As I am placed, I think my influence will be freest and best if I work by myself," he wrote to the secretary of the ISS. ${ }^{83}$ Amplifying this point, he observed to another correspondent: "I think I would cripple my influence and submit myself to a mass of needless misunderstandings if I

78. "Current Literature," Christian Socialist 4 (1 June 1907): 6-7. Representative letters include Weeks to Rauschenbusch, 22 Mar. and 28 Apr. 1904, Box 24, 4 and 7 June, and 26 Sept. 1907, Box 25, Rauschenbusch Papers.

79. Vida D. Scudder to Rauschenbusch, 21 Sept. [1912], Box 93, Rauschenbusch Papers.

80. In 1900-1918 John and Laura Rockefeller gave the Rauschenbusches about $\$ 8,000$ for personal use. Minus, Rauschenbusch, pp. 59-60, 96-97, 133-134.

81. Ibid., pp. 52, 90-91, 100, 162-163, 173-174.

82. Scudder to Rauschenbusch, 9 Oct. [1912], Rauschenbusch Papers.

83. Once he understood that the ISS promoted the study of socialism, he identified himself with it. Rauschenbusch to Algernon Lee, 17 Apr. 19ll, and to James Franklin, 17 Aug. 19ll, Box 26, Rauschenbusch Papers. 
joined the party. The members of the party would exploit my connection to cover many of their own shortcomings. But I am in friendly co-operation with them. Many of them call me 'comrade,' and you will appreciate what that means." 84 Eight years after his death, Rauschenbusch's widow confirmed that fear of diminished influence was one reason that he had stayed out of the party. In a touching letter to Eugene V. Debs, she recalled Rose Pastor Stokes's visit to Rochester. After trying to induce him to join, and then hearing this reason, Stokes "begged him not to join it." "That did not prevent his voting the Socialist ticket of course," Pauline Rauschenbusch added. ${ }^{85}$

The rise of the socialist movement claimed the attention of Social Gospel leaders. Though the intensity of the engagement varied, socialism was of more than peripheral interest to three of the Social Gospel's most representative figures. However unitive Social Gospel principles-such as the Kingdom of God, the "fatherhood of God" and "brotherhood of man," and social salvation-may seem on the surface, they led to no unanimity when it came to socialism. From Peabody's repugnance, through Gladden's attempt at evenhandedness, to Rauschenbusch's contemplation of party membership, differences in temperament, biblical hermeneutics, life experiences, perceptions of class interests, and closeness to socialist networks shaped social gospelers' judgments. That socialism, whether as rival or as parallel idealistic force, demanded a response from Christians, there could be no argument. As to what that response should be, the Social Gospel offered no common answer.

84. Rauschenbusch to L. B. Avery, 12 June 1914, Box 28, Rauschenbusch Papers.

85. Pauline Rauschenbusch to Eugene V. Debs, 3 May 1926, The Papers of Eugene V. Debs, 1834-1945 (microfilm ed., 1983), reel 4, Indiana State University, Terre Haute, Ind. 